\title{
Comentários Acerca da Regularização Fundiária Urbana do Pirambu
}

\section{Thiago Alves Henrique da Costa}

Mestre em Planejamento em Políticas Publicas - UECE

\section{Roselane Gomes Bezerra}

Doutora em Sociologia pela Universidade Federal do Ceará - UFC

Professora do Programa de Pós-Graduação em Avaliação de Políticas Públicas (MAPP) - UFC

\section{Resumo}

O presente trabalho, consiste em uma análise acerca da regularização fundiária urbana no Bairro do Pirambu na cidade de Fortaleza sob o aspecto da medida provisória no 2.220/2001 e seus impactos sociais na vida dos moradores da referida comunidade. Ademais busca-se, demonstrar que o instituto da regularização fundiária urbana realizado através da concessão especial de uso para fins de moradia contido na mencionada lei e aplicada ao bairro, pode ser considerada uma politica pública habitacional tendo em vista que o referido instituto, utiliza imóveis públicos federais na promoção do direito social à moradia, mediante a regularização fundiária daqueles que ocupam os próprios habitacionais com fins habitacionais. O benefício da política pública habitacional, através do referido instituto de regularização fundiária, é comprovado no estudo através da análise do caso prático do Pirambu utilizando uma pesquisa quantitativa e exploratória, onde pode-se identificar no caso especifico, que tal ação governamental de implementação habitacional, coaduna-se com os anseios locais configurados pelo fato dos moradores não aceitarem qualquer conduta por parte do poder público que promova a remoção dos membros da comunidade. Por fim, a principal conclusão que o presente artigo busca demonstrar é que a regularização fundiária urbana no bairro do Pirambu, assim como qualquer outra intervenção promovida pela administração pública no espaço urbano, deve levar em consideração os aspectos sociais, econômicos e culturais ajustando as ações governamentais ao lugar que se pretende promover intercessões de natureza urbana com vistas a garantia do direito social à moradia.

Palavras-chave: Regularização Fundiária. Pirambu. Políticas Públicas. 


\section{Abstract}

The present work consists of an analysis of the urban land regularization in the Pirambu neighborhood in the city of Fortaleza under the aspect of provisional measure 2,220 / 2001 and its social impacts on the life of the inhabitants of the said community. In addition, it is sought to demonstrate that the institute of urban land regularization carried out through the special use concession for housing purposes contained in the aforementioned law and applied to the neighborhood can be considered a public housing policy since the said institute uses real estate Federal public in the promotion of the social right to housing, through land regularization of those who occupy their own housing for housing purposes. The benefit of the public housing policy, through the said land regularization institute, is proven in the study through the analysis of the practical case of Pirambu using a quantitative and exploratory research, where it can be identified in the specific case, that such governmental action of housing implementation, Is in line with the local yearnings that are shaped by the fact that the residents do not accept any conduct on the part of the public power that promotes the removal of community members. Finally, the main conclusion that the present article seeks to demonstrate is that urban land regularization in the Pirambu neighborhood, as well as any other intervention promoted by the public administration in urban space, must take into account the social, economic and cultural aspects by adjusting the actions Governmental organizations to the place that is intended to promote intercessions of an urban nature with a view to guaranteeing the social right to housing.

Key words: Land regularization. Pirambu. Public policy 


\section{Introdução}

Este trabalho consiste em demostrar a importância da regularização fundiária urbana no Pirambu no Município de Fortaleza por meio da concessão especial de imóvel público com fins habitacionais considerando esta como uma politica habitacional, compatível com os anseios da comunidade local levando em consideração a opinião desta, na construção da solução desta problemática, em consonância com a garantia ao direito social da moradia e a supremacia do interesse público.

A metodologia adotada consistiu na leitura e analise da tese de mestrado relacionada ao assunto bem como em literaturas acerca do tema chegando à conclusão de que a participação do pesquisador e da comunidade envolvida juntamente com a análise do contexto histórico e social do Pirambu são os grandes instrumentos norteadores para a eficácia de politicas públicas de regularização fundiária urbana no bairro sob a ótica da utilização de imóveis públicos federais para fins habitacionais.

As diversas transformações que a administração pública vem passando ao logo do processo histórico e suas condutas perante a garantia do direito fundamental a moradia consubstanciado através das políticas públicas vem gerando instabilidade no que se refere aos meios empregados pelo Estado para promover tais direitos em razão da forma obtusa como este considera qual seria a melhor forma de promover à regularização fundiária trazendo consigo tais manifestações estatais na maioria das vezes, traços totalitaristas, identificado principalmente em seus atos administrativos sem ouvir a comunidade, servindo muitas vezes apenas ao interesse privado em vez da coletividade ou ao próprio estado em si.

A questão da problemática urbana nas cidades no que se refere à falta de moradia sempre foi encarada como uma situação complexa a ser enfrentada pelo poder público em todo o processo histórico de formação do espaço urbano brasileiro.

É fato que a informalidade habitacional apresentar-se como um problema crônico que ocorre em quase todas as cidades brasileiras associadas em grande parte a populações de baixa renda ocupantes de imóveis irregulares caracterizados por uma situação de insegurança jurídica permanente configurada esta por sua vez pelo medo da remoção ou desocupação.

\section{Considerações iniciais acerca da regularização fundiária urbana como política pública}

A construção de uma politica pública urbana habitacional, pelo fato de não haver uma definição precisa sobre o que seja politica pública, conforme Mead (1995) quando a 
define como um campo dentro do estudo da politica que analisa o governo a luz de grandes questões públicas e Lynn (1980) ou como um conjunto de ações do governo que irão produzir efeitos específicos segundo Peters (1986) abre margem ao entendimento de que esta deve partir da sociedade advinda de qualquer segmento desta.

Essa indefinição da conceituação da politica pública deve-se também pelo fato de que por ser um ramo das ciências sociais que estudam a inter-relação entre Estado e sociedade utiliza-se de outros ramos específicos das ciências humanas voltados ao estudo do homem e de seu comportamento social dentro de ambientes sociais próprios da vida privada como a filosofia, antropologia, psicologia e por essa razão podendo, portanto a politica pública advir do próprio homem sem a necessidade da ação do poder público como requisite indispensável para caracterização da politica pública.

Assim, a indefinição do conceito de politica pública de que esta sob o aspecto do panorama da regularização fundiária urbana pode e dever surgir ou ter participação da população em sua implementação e não necessariamente advir apenas do poder estatal.

Nesse sentido, sob o contexto urbanístico onde as grandes cidades sofrem o influxo dos interesses hegemônicos do sistema de produção capitalista, entregando à alienação os seus espaços para o comércio de bens e serviços passando a se desenvolver em movimentos seletivos, excluindo as precárias habitações a politica pública urbana voltada a reorganização do espaço, mas precisamente da moradia nas cidades de certa forma acaba construindo seus preceitos basilares com a participação primordial dos atores envolvidos no processo.

Observam-se entre os agentes sociais a coalização de forças em face que pode coadunar-se ou não terceiros ou poder estatal onde estes personagens que muitas vezes são tidos como elementos hostis sob os aspectos da identidade da população envolvida no contexto sócio espacial quando a administração pública muitas vezes deseja realizar intervenções sem se quer consultar a população local acerca das possíveis mudanças. (BOURDIEU, 2012, p. 126-127), com precisão, acentua a disposição dos dominados em lutar:

A reivindicação regionalista, por muito longínqua que pareça deste nacionalismo sem território, é também uma resposta à estigmatização que produz o território de que, aparentemente, ela é produto. $E$, de facto, se a região não existisse como espaço estigmatizado, como província definida pela distância económica e social (e não geográfica) em relação ao centro, quer dizer, pela privação do capital (material e simbólico) que a capital concentra, não teria que reivindicar a existência: é porque existe como unidade negativamente definida pela dominação simbólica e económica que alguns dos que nela participam podem ser levados a lutar (e com probabilidade objetiva de sucesso e de ganho) para alterarem o sentido e o valor das características 
estigmatizadas, e que a revolta contra a dominação em todos os seus aspectos - até mesmo económico - assume a forma da reivindicação regionalista.

Tal elemento que promove a coesão de grupos sociais no sentido de lutar por seus direitos resulta conforme preconiza Max Weber, de um "sentimento subjetivo de partícipes de constituição de um todo", somado a ideia de "compensação de interesses por motivos racionais, ou então numa união de interesses com idêntica motivação" (WEBER, 1973, p. 140 in FERNANDES, 1997).

A identificação dos atores sociais com o seu espaço habitual de modo a lhe propiciar melhores condições de vida faz com que ao se efetuar uma regularização fundiária, leva-se em consideração não apenas os aspectos estruturais, mas principalmente antropológicos, pois a inobservância de tal aspecto resultará no marco inicial de conflitos sociais pela luta da terra não podendo haver o desligamento da população com o seu meio social quando se tem uma vida já em curso. (MONGIN, 2009), sob esse aspecto, entende não ser correta a retirada dos atores sociais de seus lugares, entendendo que a junção entre o grupo social e seu lugar deve ser tida como características da formação do espaço urbano havendo para tanto um empenho por parte de tais grupos de buscar tal reconhecimento através da luta social.

O urbanismo deve coadunar-se com a correção social e do espaço existente paralelamente a regularização fundiária objetivando estabelecer (MAFFESOLI, 2010) que as políticas públicas voltadas à regularização fundiária urbana, esta deve ser aplicada sempre levando consideração as necessidades das camadas sociais mais carentes tendo distribui melhor a cidade sob o aspecto da moradia e dos equipamentos urbanos amenizando diversos problemas estruturais e sociais desde a violência até falta de saneamento básico, pois "a cidade tem por missão especial conciliar concordância e discordância, discórdia e consenso". (MONGIN, 2009, p. 77).

Nesse contexto de conviç̧ões sociais e filosóficas acerca da indefinição da conceituação de politicas públicas e na exaltação da sociedade em criar e administrar suas próprias politicas públicas com o escopo de resolver seus problemas, mas especificamente o de moradia urbana, Constituição da Republica Federativa do Brasil de 1988, estabeleceu princípios constitucionais como a função social da propriedade e o direito social a moradia, encontram-se norteados ao bom cumprimento do uso sustentável da propriedade quer seja esta pública ou privada e que devem ser levados em consideração principalmente para chancelar as condutas da sociedade na busca da habitação.

Tal necessidade em estabelecer parâmetros para o bom desempenho da função social da propriedade pública voltada para a questão da moradia deu ensejo ao surgimento de um sistema jurídico de regularização fundiária com vistas a garantir a moradia, composto principalmente pelo Estatuto das Cidades e Medida Provisória no 2.220/2001 que acabam 
impondo até mesmo ao próprio poder público a obrigatoriedade de regularizar a situação de moradia daqueles que ocupam imóveis urbanos mesmo de natureza pública, obviamente em certas condições previstas em lei.

Paralelamente é importante salientar o quanto é importante à regularização fundiária urbana consubstanciada nos moldes do direito social à moradia, pois esta é condição para aplicabilidade de outros direitos fundamentais como educação e saúde, por exemplo, tornando-se, portanto um instrumento catalizador de transformação social com vistas à qualidade de vida de qualquer comunidade a qual for implantada sendo muito mais do que uma mera legitimação da posse.

Tal entendimento é compartilhado pelo nobre Pesquisador Mauricio Moura que em estudo na cidade de Osasco no Estado de São Paulo constatou que a regularização fundiária aumenta a jornada de trabalho, a renda familiar, e ainda diminui o trabalho infantil. Isso se explica porque a insegurança jurídica quanto à situação de moradia prejudica o envolvimento e a dedicação das famílias a outras atividades. No Brasil, em relação ao contexto da politica pública de moradia percebe-se no processo histórico a permanência de diversas comunidades sociais sob o aspecto da luta pela garantia do direito a moradia. (KOWARICK, 1994).

Os segmentos sociais que lutam pelo direito a habitação digna concentram sua luta na regularização fundiária de loteamentos clandestinos independente da área ser privada ou pública como, por exemplo, Movimento Nacional de Reforma Urbana autor das propostas para a Assembleia Constituinte de 1987 relacionadas ao direito à moradia e que hoje tem assento no Conselho Nacional das Cidades junto ao Ministério das Cidades sendo de fundamental importância para não apenas programar como também para participar diretamente da criação de politicas públicas de habitação tendo em vista que os atores sociais envolvidos na garantia do direito a moradia membros dos movimentos sociais de luta por habitação são os grandes conhecedores das demandas que afligem tais segmentos sociais. (SAULE JÚNIOR, 1999). Fernandes coaduna com tal entendimento:

\footnotetext{
A participação dos atores sociais, implicando em assegurar um ambiente político institucional e legal que facilite sua participação efetiva em todas as etapas do desenvolvimento sustentável; d) igualdade de gênero; e) financiamento da habitação e assentamentos humanos; f) cooperação internacional; g) avaliação dos progressos (FERNANDES, 2006, p. 32).
}

Some-se a isso, a omissão estatal nas periferias das grandes cidades, gerando politicas públicas determinadas pela própria população local que podem ser consideradas como tais, pelo fato de não haver na literatura um conceito determinado de politicas públicas, 
pois esta não depende não depende para sua criação e execução apenas do poder estatal e de uma estrutura pública e física, assim preconiza (RUA, 2009, p. 27) quando diz que "embora uma politica pública implique uma decisão politica, nem toda decisão politica chega a constituir uma politica pública".

Dessa forma, percebe-se a importância da regularização fundiária urbana e sua condição de politica pública transformadora não apenas sob o aspecto espacial, mas também social e da participação efetiva da sociedade em sua condução.

\section{O contexto histórico do Pirambu}

O bairro tem origem no êxodo rural onde depois foi transformado em centro urbano problemático, possuindo um característica peculiar de movimentos partidários, resistência, foco irradiador de movimentos sociais contra a pobreza persistente mas que ao mesmo tempo possui um forte reflexo popular mas que por outro lado ainda apresenta-se com um aglomerado subnormal dos mais latentes do pais e o mais carente da cidade de Fortaleza.

A pobreza latente do bairro Pirambu remete aos ensinamentos de Deleuze (1998, p. 224), no sentido de que o modo de produção capitalista acentua em grande escala a miséria das populações "pobres demais para a dívida, numerosos demais para o confinamento: o controle não só terá que enfrentar a dissipação das fronteiras, mas também à explosão dos guetos e favelas".

Dentro do contexto histórico existem fatores que identificam o surgimento e desenvolvimento do Pirambu, como o Decreto 1058 e o hino que de certa forma fortaleceram a ideia de que o bairro é diferenciado, politizado e resistente às mudanças da Metrópole. A "Marcha do Pirambu" que ainda hoje é lembrada como um dos marcos social mais importante para a população carente de Fortaleza foi, lembrando as lições de Bauman (2008), onde a população pobre do Pirambu procurou manter um bom convívio social entre seus pares sempre em busca da manutenção da moradia e do bem estar da comunidade.

Outro importante marco que caracteriza a historia do Pirambu e sua forma são o Decreto no 1.058, o hino cristão-revolucionário do Pirambu, o Partido Comunista Brasileiro (PCB), a universidade, as Organizações Não Governamentais (ONG's), bem como movimentos religiosos e de combate à ditadura que de certa forma juntos dão a real identidade do bairro das pessoas.

O fato é que diante de todos esses fatos que identificam e constroem o Pirambu a luta, à resistência contra todas as ações estatais que ameaçam o convívio é o elemento mais identificador da comunidade já que "resistir à opressão foi e continua sendo o grande desa- 
fio da humanidade”. (BUZANELLO, 2003, p. 54). Em relação a essa característica principal de resistência pode-se dizer que tal conduta é o principal vetor que manteve ate os dias atuais a comunidade estável diante dos problemas internos e externos enfrentados.

As diversas incursões tentadas pelo poder público, não tiveram êxito restaram malsucedidas porque a população foi mal ouvida. No curso da pesquisa pode-se ver que o "papel da casa", como é comumente referido o processo de regularização fundiária, acena para uma possibilidade de abrir o lugar para toda sorte de fluxos (especulação imobiliária, transportes públicos, comércio massificado etc.). Não se faz juízo de valor sobre a conveniência de tais obras para a população do Pirambu, mas somente se volta à dissertação para a verificação da percepção das pessoas envolvidas na trama urbana, daí o forte conteúdo etnográfico do estudo.

Nesse sentido, percebe-se que o Pirambu continua como centro estratégico da politica municipal e estadual e grande laboratório sociológico para aplicação de políticas públicas, seja pela acentuada densidade demográfica, seja pela histórica omissão estatal na destinação de bens e serviços públicos àquela área da zona oeste da cidade e neste cenário a moradia encontra-se como fator primordial de estabilidade e bem estar local. É assim que a ideia de analisar a regularização fundiária de imóveis públicos federal utilizada para moradia com ênfase na titulação da propriedade e segurança jurídica contra terceiros ou contra o próprio poder estatal.

Os movimentos sociais por anos travam lutas por diversos direitos sociais que determinem o mínimo existencial de dignidade de sobrevivência principalmente pela habitação. Apesar de que desde o surgimento do bairro com o êxodo rural passando pela migração urbana ate os dias atuais várias conquistas foram conquistadas, mas pelo fato da comunidade possuir diversidade de problemas em suas peculiaridades a eficácia da solução destes nem sempre se concretiza principalmente em relação à questão habitacional.

A questão da moradia urbana é problema crônico tendo em vista o bairro possuir a maior densidade demográfica de Fortaleza, sendo o terceiro pior bairro da Metrópole em condições domiciliares, levando-se em consideração cinco aspectos de infraestrutura: proporção de domicílios ligados à rede geral de água, esgotamento sanitário, energia elétrica e servida por coleta sistemática de lixo. Tais aspectos da infraestrutura servem de parâmetro para o cálculo de Índice Sintético de Condições Domiciliares (ICD) idealizado pelo Instituto de Pesquisa e Estratégia Econômica do Ceará - IPECE (2002).

A densidade habitacional tem repercussões relevantes no espaço urbano. Sabe-se que os aspectos físicos de um lugar está atrelado à quantidade de habitantes influenciam diretamente a qualidade de vida destes, pois sem espaço suficiente para acomodar as habitações gerando de certa forma um descompasso urbanos que inviabiliza a moradia digna e a prestação de serviços públicos. 
Nesse contexto é importante salientar que o Pirambu apresenta áreas de situação de risco que de certa forma necessitam de remoção e que apresentam uma forma peculiar de situação peculiar de regularização fundiária.

É importante salientar que quando houver situações de risco não haverá possibilidade de se implementar a regularização fundiária em áreas de risco, pelo menos antes de se adotar as medidas técnicas preconizadas para a eliminação ou contenção de riscos a integridade física e a saúde dos moradores de modo que as famílias residentes em área de risco e em áreas de preservação permanente devem ser relocadas para unidades habitacionais situadas o mais próximo possível de suas antigas moradias objetivando manter as relações comunitárias evitando com isso a possibilidade de resistência dos moradores em sair do local ou retornarem.

O fato é que em todo o processo histórico de formação do bairro, é marcado primeiramente por lutas sociais de membros da comunidade principalmente contra particulares que se diziam verdadeiros proprietários da área apresenta na atual conjuntura embates da comunidade agora contra o Governo do Estado e o Governo Municipal tendo em vista que estas esferas estatais executam politicas publicas de urbanização na área do Pirambu, sempre atribuindo as estas condições de remoção dos ocupantes e sem consulta-los acerca da urbanização do espaço.

\section{Aspectos legais da regularização fundiária do bairro}

A regularização fundiária do grande Pirambu, inicialmente ocorreu através do Decreto Federal no 1.058, de 25 de maio de 1962, publicado no Diário Oficial da União de maio de 1962, Seção I, Parte I, onde foram desapropriadas em favor da União Federal, duas glebas onde hoje se localiza o bairro, uma com 525.000,00 m², e outra com $986.000,00 \mathrm{~m}^{2}$ tratadas respectivamente nas matriculas de ํㅡ 43.701, 43.702 do Cartório de Registro de Imóveis da $3^{\circ}$ Zona da Comarca de Fortaleza, Ceará. Posteriormente essa glebas foram unificadas num total de $1.511 .000,00 \mathrm{~m}^{2}$, registrada sob matrícula 61.126 do mesmo cartório.

Trata-se de área urbana consolidada nos ditames da Lei 11.977, artigo 47, pois possui densidade demográfica superior a 50 (cinquenta) habitantes por hectare, malha viária implantada, drenagem de águas pluviais, esgotamento sanitário em vários trechos, abastecimento de água potável, distribuição de energia elétrica, limpeza urbana, coleta e manejo de resíduos sólidos.

A área teve sua origem também na declaração de utilidade pública, promovida pelo mesmo Decreto Federal no 1.058/ 1962 publicado no DOU de 25 maio de 1962, Seção I, Parte 
I, para desapropriação em favor da União Federal, de duas glebas no Pirambu (uma com $525.000,00 \mathrm{~m}^{2}$, e outra $986.000,00 \mathrm{~m}^{2}$ ), necessárias ao melhoramento habitacional local, com a execução de plano urbanístico, obras de higiene, aberturas de vias e logradouros públicos, e objetivando a fixação dos habitantes.

Pela Portaria no 96, de 08 de abril de 2008, foi declarada a nulidade de inscrições de ocupação de imóveis localizados no bairro Pirambu, tendo em vista os erros cometidos quando do cadastramento dos mesmos e o obstáculo que esse cadastramento errado traria a regularização fundiária dos moradores.

O presente processo foi encaminhado ao setor de Arquitetura da Superintendência do Patrimônio da União Federal no Estado do Ceará para que fosse acostado ao mesmo, planta de localização e situação do terreno com áreas testadas, confinantes, identificação de quadra e lote e seu memorial descritivo.

Tendo em vista ser o imóvel predominantemente ocupado por população de baixa renda, e em face de necessidade de formalizar garantias ao ocupante, observando o que dispõe o Decreto-Lei no 2.398 de 21 de dezembro de 1987, artigo 5, paragrafo único, a área do Pirambu foi declarada de interesse do serviço público nos termos da portaria no 198, de 07 de agosto de 2006 (Portaria emitida pelo Secretário do Patrimônio da União Federal). Vejamos:

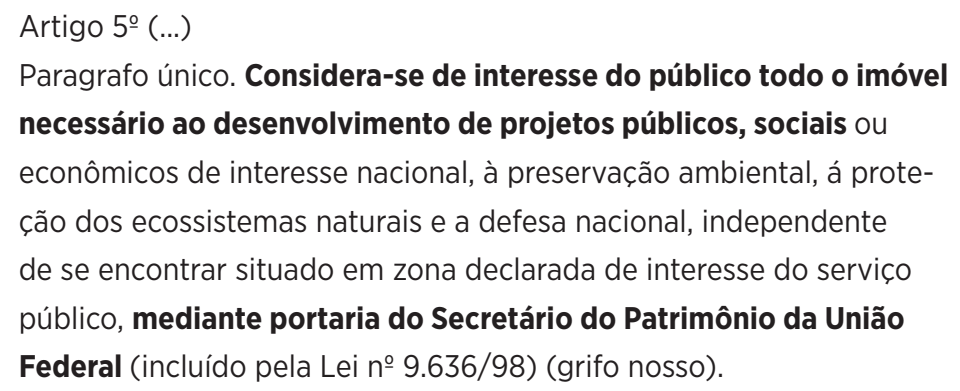

\section{A concessão especial de moradia em imóvel público no bairro}

Após breves considerações acerca da origem jurídica do bairro dentre os diversos instrumentos jurídicos voltados à regularização fundiária urbana o mais ajustável com a realidade social e espacial do bairro é a Concessão de Uso Especial para fins de Moradia prevista na Medida Provisória - MP 2.220/2001 tendo em vista que o contexto de regu- 
larização fundiária urbana emanada da referida normatização tem como núcleo central o direito à moradia que, sem dúvida, representa no mundo moderno um dos direitos fundamentais mais importantes no sentido de promover políticas públicas para habitação. É o que mostra Di Pietro (2002, p.160):

O instituto da concessão especial para fins de moradia atende ao evidente interesse social, na medida em que se insere como instrumento de regularização da posse de milhares de pessoas de classes mais pobres, em regra faveladas, contribuindo para ampliar a função social inerente à propriedade pública.

É necessário, portanto, que o referido instituto de regularização fundiária urbana aplicada ao caso do Pirambu, seja conhecido na integra para que através de sua compreensão, perceba-se a natureza de politica pública para fins habitacionais que possui bem como o motivo pelo qual tal normatização foi bem aceita pela população da comunidade, qual seja a remoção dos habitantes é tida pelo referido dispositivo com exceção.

Para ter direito à concessão especial para fins de moradia, foi necessário que os moradores locais preenchessem determinados requisitos, conforme preceitua o caput do Art. $1^{\circ}$ da Medida Provisória nº 2.220/2001 que contém a seguinte redação:

Art. 1- - Aquele que, até 30 de junho de 2001, possuiu como seu, por cinco anos, ininterruptamente e sem oposição, até duzentos e cinquenta metros quadrados de imóvel público, situado em área urbana, utilizando-o para sua moradia ou de sua família, tem o direito à concessão de uso especial para fins de moradia em relação ao bem objeto da posse, desde que não seja proprietário ou concessionário, a qualquer título, de outro imóvel urbano ou rural.

Em níveis de imóveis públicos federais, a concessão especial de uso para fins habitacionais aplica-se a áreas da União Federal inclusive, os terrenos de Marinha. No entanto o diploma legal veda a incidência do instituto sobre imóveis funcionais conforme artigo 22-A da Lei Federal no 9.636/1998:

Art. 22 - A. A concessão de uso especial para fins de moradia aplica-se às áreas de propriedade da União, inclusive aos terrenos de marinha e 
acrescidos, e será conferida aos possuidores ou ocupantes que preencham os requisitos legais estabelecidos na Medida Provisória no 2.220. de 4 de setembro de 2001.

Outro aspecto que parece relevante é o fato do referido instituto, seja ele formalizado por termo administrativo, ou seja, por sentença judicial, ser registrado no Cartório de Registro de Imóveis conforme preconiza o artigo 167 da Lei Federal n 6.216/1975 “Art. 167 - No Registro de Imóveis, além da matrícula, serão feitos. I - o registro: 40) do contrato de concessão de direito real de uso de imóvel público”.

Além disso, o titulo de concessão possui a natureza vinculada para o fim de reconhecer ao ocupante de imóvel público o direito subjetivo à moradia, desde que cumpridos os requisitos legais já expostos no início deste capitulo, é o que preconiza o §2ำ do artigo 1ㅜ, da Medida Provisória n 2.220/2001 “§ 20 O direito de que trata este artigo não será reconhecido ao mesmo concessionário mais de uma vez".

A formalização da concessão para moradia pode efetivar-se por termo administrativo realizado na situação em epigrafe por técnicos da Secretaria do Patrimônio da União em conjunto com servidores da Fundação de Desenvolvimento Habitacional de Fortaleza, quando o pedido for atendido na esfera administrativa, sem a necessidade de levar tal feito ao judiciário exceto se denegado o pedido de ocupação ou no caso de omissão do referido serviço público em apreciá-lo. Assim, em qualquer dessas situações haverá necessidade de registro no Cartório de Registro Imobiliário.

É importante salientar que alguns casos, a lei admite que o possuidor possa obter a concessão em outro local. Nesses casos, pressupõe-se que o imóvel ocupado pelo possuidor provoque risco à vida ou à saúde dos possuidores, ficando nesse caso garantido ao concessionário o direito subjetivo em local diverso, não podendo a administração pública decidir de forma diferente, como prescreve o artigo que se segue. Vejamos:

Art. 40 No caso de a ocupação acarretar risco à vida ou à saúde dos ocupantes, o Poder Público garantirá ao possuidor o exercício do direito de que tratam os artigos 1o e 20 em outro local.

Corroborando ainda neste sentido, existem situações previstas no artigo 5o onde legislador, diferentemente do que foi conferido no artigo $4^{\circ}$ concedeu que à administração pública pudesse, utilizando seu poder discricionário, a faculdade de transferir o ocupante de imóvel público para outro local, veja: 
Art. 50 É facultado ao Poder Público assegurar o exercício do direito de que tratam os arts. 10 e 20 em outro local na hipótese de ocupação de imóvel:

I - de uso comum do povo

II - destinado a projeto de urbanização;

III - de interesse da defesa nacional, da preservação ambiental e da proteção dos ecossistemas naturais;

IV - reservado à construção de represas e obras congêneres; ou

$\mathrm{V}$ - situado em via de comunicação.

É importante enfatizar que a concessão especial para fins de moradia pode extinguir-se nas seguintes hipóteses:
Art. 80 O direito à concessão de uso especial para fins de moradia extingue-se no caso de:
I - o concessionário dar ao imóvel destinação diversa da moradia para
si ou para sua família; ou
II - o concessionário adquirir a propriedade ou a concessão de uso de outro imóvel urbano ou rural.
Parágrafo único. A extinção de que trata este artigo será averbada no cartório de registro de imóveis, por meio de declaração do Poder Público concedente.

O legislador, ainda, curvando-se às exigências urbanísticas estabeleceu a concessão especial para fins de moradia de imóveis públicos, de forma coletiva, diante de situações em que não há possibilidade de ser identificado separadamente cada imóvel público ocupado por possuidor. Vejamos:

Art. 20 Nos imóveis de que trata o art. 10, com mais de duzentos e cinquenta metros quadrados, que, até 30 de junho de 2001, estavam ocupados por população de baixa renda para sua moradia, por cinco anos, ininterruptamente e sem oposição, onde não for possível identificar os terrenos ocupados por possuidor, a concessão de uso especial para fins de moradia será conferida de forma coletiva, desde que os possuidores não sejam proprietários ou concessionários, a qualquer título, de outro imóvel urbano ou rural. 
Paralelamente é importante enfatizar que caso ocorra uma concessão coletiva, onde a cada beneficiário será atribuída igual fração ideal do terreno, não será levado em conta à dimensão do terreno que cada possuidor ocupe. Ressalva-se apenas que haja a celebração de acordo entre ocupantes, no qual pode ser pactuada a atribuição de frações ideais diferenciadas, devendo considerar que nesse caso o instituto da concessão para fins de moradia em imóveis públicos visa promover a regularizar fundiária até mesmo nos caso em que ocorra uma situação onde não se possa definir um número determinável de pessoas.

O fato é que o referido instituto da regularização fundiária urbana tornou-se o que mais se coaduna com a realidade da comunidade do Pirambu tendo em vista que o mesmo apresenta-se com um cunho social identificado pelo fato de em regra, regularizar os beneficiários no lugar em que já residem tendo como exceção possibilidade da remoção somando-se a isso sua característica módica e dinâmica sob o aspecto do tempo em que o imóvel público ocupado é regularizado.

Tal característica somada à situação dinâmica da própria natureza do instituto, caracterizada pela natureza vinculativa no que se refere ao direito do beneficiário obter o referido titulo inclusive sujeitando a própria administração pública em concedê-lo além do caráter modico e de baixo custo justamente por não privilegiar a remoção fizeram deste uma politica pública de regularização fundiária urbana bem recepcionada pela população do Pirambu.

\section{Considerações Finais}

Deveras, é perceptível de imediato que, se encontra um poder estatal que pouco prioriza o investimento habitacional popular sob a ótica do aproveitamento do patrimônio público. Sobre a mesma vertente, o capital privado consubstanciado pela especulação imobiliária que cada vez mais trata o direito a moradia não como um direito social, mas como um produto de mercado para aqueles mais carentes sempre sob o discurso que tal aporte configura-se em investimento econômico e geração de emprego e renda dificultando o acesso das camadas sociais mais carentes ao sonho da casa própria.

Anote-se que apesar de haver regularização fundiária em toda a sua totalidade beneficiando de aproximadamente 10.511 famílias Segundo dados da Secretaria do Patrimônio da União Federal no Estado do Ceará a comunidade ainda encontra-se interligada por diversas mazelas sociais como falta de saneamento básico partindo do pressuposto que o espaço precisa de mais investimentos advindos do setor público e enquanto isso não ocorre a própria população vai estabelecendo seus ditames de sobrevivência. 
É evidente que a administração pública em todas as esferas deve reavaliar a execução de seus programas habitacionais de moradia onde estes sempre devem estar em consonância com os instrumentos jurídicos de regularização fundiária, previstos em nosso marco legal, voltado o acesso à propriedade pública das famílias de baixa renda, configurado pelo direito à moradia com ênfase em áreas públicas reconhecidos por nosso ordenamento jurídico bem como dos anseios da própria sociedade envolvida no processo de regularização fundiária que sabe o que necessita e que sempre deve ser consultada e inserida na pauta dos projetos de execução de politicas públicas habitacionais cada vez mais complexos tendo em vista o alto grau de densidade urbana principalmente das capitais brasileiras.

O fato é que verificou-se na aplicação da politica pública da regularização fundiária do Pirambu um verdadeiro processo de construção coletiva em relação ao uso do bem público que ao mesmo tempo em que possuem a característica de ser propriedade de toda a sociedade devem transcender os interesses estatais pois servir aos outros de forma individual concedendo o direito social à moradia também é interesse coletivo. A consolidação de tal entendimento depende da participação efetiva dos grupos sociais envolvidos através de instâncias colegiadas que sempre em seu processo histórico promoveram tomadas de decisões quanto à destinação de seus grupos sociais em diversas vertentes das politicas públicas, servindo muitas vezes como instância de democratização da gestão dos bens públicos e dos próprios membros da coletividade.

Assim, foi como agiu o poder público federal e os moradores do bairro do Pirambu onde os próprios grupos sociais em parceria com a administração pública contribuíram no sentido informar aos demais habitantes a finalidade da concessão de moradia em imóvel público e a titularização o que de certa forma, contribuiu para a estabilidade social e execução da regularização tendo em vista o referido estatuto coaduna-se com o anseio básico da comunidade que é a desnecessidade de remoção dos moradores, pois estes não estão ligados apenas a terra, mas principalmente ao lugar como um todo a sua história e a sua cultura.

Reconhecendo o referido regime como vetor principal na execução de politicas públicas habitacionais e catalizador do déficit habitacional urbano local. 


\section{Referências Bibliográficas}

BAUMAN, Zygmunt. A sociedade individualizada. Rio de Janeiro: Zahar, 2008.

BOURDIEU, Pierre. O poder simbólico. Rio de Janeiro: Bertrand Brasil, 2012.

BRASIL. Lei n 11.977, de 7 de julho de 2009. Dispõe sobre o Programa Minha Casa, Minha Vida - PMCMV e a regularização fundiária de assentamentos localizados em áreas urbanas; altera o Decreto-Lei no 3.365, de 21 de junho de 1941, as Leis nos 4.380, de 21 de agosto de 1964, 6.015, de 31 de dezembro de 1973, 8.036, de 11 de maio de 1990, e 10.257, de 10 de julho de 2001, e a Medida Provisória no 2.197-43, de 24 de agosto de 2001; e dá outras providências. Disponível em: http://www.planalto.gov.br/ccivil_03/_ato2007-2010/2009/ lei/I11977.htm. Acesso em 13 out. 2016

BRASIL. Medida Provisória № 2.220, de 4 de setembro de 2001: dispõe sobre a concessão de uso especial de que trata o artigo.183 da Constituição,cria o Conselho Nacional de Desenvolvimento Urbano- CNDU e dá outras providências. Disponível em: <http://www. planalto.gov.br/ccivil_03/mpv/2220.htm>. Acesso em: 8 nov. 2015.

BRASIL. Lei № 9.636, de 15 de maio de 1998. Dispõe sobre a regularização, administração, aforamento e alienação de bens imóveis de domínio da União, altera dispositivos dos Decretos-Leis n오 9.760, de 5 de setembro de 1946, e 2.398, de 21 de dezembro de 1987, regulamenta o § 2 do art. 49 do Ato das Disposições Constitucionais Transitórias, e dá outras providências. Disponível em:<http://www2.camara.leg.br/proposicoesWeb/prop_ mostrarintegra;jsessionid=. Acesso em: 14 jun. 2016.

BRASIL. Decreto-lei no 2.398, de 21 de dezembro de 1987. Dispõe sobre foros, laudêmios e taxas de ocupação relativas a imóveis de propriedade da União, e dá outras providências. Disponível em: http://www.planalto.gov.br/ccivil_03/decreto-lei/1965-1988/Del2398.htm. Acesso em: 18 abril 2016. 
BRASIL. LEI No 6.216, DE 30 DE JUNHO DE 1975. Altera a Lei no 6.015, de 31 de dezembro de 1973, que dispõe sobre os registros públicos. Disponível em: http://www.planalto.gov. br/ccivil 03/leis/L6216.htm. Acesso em: 15 maio 2016.

BRASIL. Decreto do Conselho de Ministros no 1.058, de 25 de maio de 1962. Declara de utilidade pública, para desapropriação, duas áreas de terra situadas no bairro Pirambu, em Fortaleza, capital do Estado do Ceará, necessárias a melhoramento habitacional de grande centro de população local, com execução de plano de urbanização, obras de higiene e abertura de vias e logradouros públicos, para melhor utilização estética e fixação dos habitantes respectivos. Diário Oficial da União, Poder Executivo, Brasília, DF, 25 maio 1962. Seção 1, p. 5827. Disponível em: <http://www2.camara.leg.br/legin/fed/decmin/1960- 1969/decretodoconselhodeministros-1058-25-maio-1962-353017-publicacaooriginal- 1-pe.html>. Acesso em: 12/09/2016

BUZANELLO, José Carlos. Direito de resistência constitucional. Rio de Janeiro: América Jurídica, 2003.

DELEUZE, G. Diferença e repetição. Rio de Janeiro: Graal, 1988.

DI PIETRO, Maria Sylvia Zanella. Concessão de Uso Especial para Fins de Mordia (Medida Provisória 2.220, de 4.9.2001) in Estatuto da Cidade - comentários à Lei Federal 10.257/2001. São Paulo, Malheiros, 2002.

FERNANDES, Edésio. Evolução do direito urbanístico II. Heloisa Soares de Moura Costa... [et al]. - Belo Horizonte: PUC Minas Virtual, 2006.

INSTITUTO DE PESQUISA E ESTRATÉGIA ECONÔMICA DO CEARÁ. Perfil Municipal de Fortaleza. Tema IX: As Condições Domiciliares dos Bairros. IPECE Informe, Fortaleza, n. 44, edição especial, nov. 2012. Disponível em: <http://www.ipece.ce.gov.br/publicacoes/ipece-informe/Ipece_Informe_44_12_novembro_2012.pdf>. Acesso em: 20 jan. 2015. 
KOWARICK, L. Trabalho e Vadiagem: a origem do trabalho libre no Brasil. Rio de Janeiro: Paz e Terra, 1994, p. 81-100.

LYNN, L. E. Designing Public Policy: A Casebook on the Role of Policy Analysis. Santa Monica, California: Goodyear, 1980.

MAFFESOLI, M. A transfiguração do político: a tribalização do mundo. Rio de Janeiro: Forense, 2010.

MEAD, L. M. “Public Policy: Vision, Potential, Limits”. Policy Currents: 1-4. Fevereiro 1995.

MONGIN, Olivier. A condição urbana: a cidade na era da globalização. São Paulo: Estação Liberdade, 2009.

PETERS, B. G. American Public Policy. Chatham, N.J.: Chatham House. 1986.

RUA, Maria das Graças. Políticas Públicas. Florianópolis: Departamento de Ciências da Administração / UFSC, 2009. 130 p.

SAULE JÚNIOR, Nelson. A proteção jurídica da moradia nos assentamentos irregulares. Porto Alegre: Sergio Antonio Fabris Editor, 2004.

WEBER, Max. Comunidade e sociedade como estruturas de socialização. In: FERNANDES, F. (Org.). Comunidade e sociedade. São Paulo: Biblioteca Universitária, 1997. 